\title{
Averting "Carmageddon" Through Reform? An Eco-Systemic Analysis of Traffic Congestion and Transportation Policy Gridlock in Metro Manila
}

\author{
John T. Sidel \\ London School of Economics
}

\begin{abstract}
This article provides a holistic analysis of traffic congestion in Metro Manila, treating traffic and transport in the Philippines' national capital region as an ecosystem which has entrenched itself, endured, and evolved in the face of ongoing demographic, economic, and technological change. The article focuses on the activities and initiatives of a new 'species' within Metro Manila's transport ecosystem -- the transport reform advocacy group -- to identify and examine both the constituent elements and complex operations of the ecosystem and its capacities for resistance, resilience, and reconstitution in the face of 'reform'. These reform initiatives include a proposed bus rapid transit (BRT) system, the loosening of number-coding restrictions on public utility vehicles, the liberalization of Point-to-Point (P2P) bus services, the legalization of motorcycle taxis, the Public Utility Vehicle Modernization Program (PUVMP), and the establishment of bicycle lanes and the expansion and improvement of pedestrian walkways to improve 'micro-mobility' in the metropolis. The article concludes with a consideration of the efforts of transport reform advocacy groups to advance these elements of their reform agenda amidst the ongoing global pandemic and the government-imposed quarantine and economic downturn in the Philippines in early-mid 2020.
\end{abstract}

Keywords: Philippines; Duterte; Metro Manila; transport; reform

Correspondent Address: j.t.sidel@1se.ac.uk

Accepted for publication on 27 June 2020 in

Critical Asian Studies, Volume 52, Number 3 (September 2020). 
London, the crouching monster, like every other monster has to breathe, and breathe it does in its own obscure, malignant ways. Its vital oxygen is composed of suburban working men and women of all kinds, who every morning are sucked up through an infinitely complicated respiratory apparatus of trains and termini into the mighty congested lungs, held there for a number of hours, and then, in the evening, exhaled violently through the same channels. The men and women imagine they are going into London and coming out again more or less of their own free will, but the crouching monster sees all and knows better.

Patrick Hamilton, The Slaves of Solitude (1947)

\section{Introduction}

Over the course of the past decade, a steadily growing stream of critical commentary and prescriptive analysis has focused on the mounting problems associated with traffic congestion and transport infrastructure gridlock in Metro Manila and the neighboring provinces of the National Capital Region of the Philippines. Columnists and other critical commentators have emphasized the failings and foibles of politicians and policy-makers, whose incapacity for decisive, effective action and susceptibility to corruption have been cited as explanations for traffic congestion that costs commuters sixteen full days each year and the economy as a whole 3.5 billion Philippine pesos (nearly USD \$69 million) per day. ${ }^{1}$ Government policymakers, urban planners, transport specialists, consultants, and policy advocates have concentrated on putatively technical fixes like the Public Utility Vehicle Modernization Program (PUVMP), new provincial bus terminals, high-tech schemes for "smart" traffic management, and proposals for a bus rapid transit system $(\mathrm{BRT}) .^{2}$ The problems are understood to be political and the solutions to be technical, with plenty of finger-pointing at those responsible for the problems, on the one hand, and power-pointing by those responsible for the solutions, on the other. But meanwhile, a decade has elapsed and the problems have persisted if not worsened.

\footnotetext{
${ }^{1}$ De Vera 2018.

${ }^{2}$ See, for example, Intelligent Transport Society of Korea 2018.
} 


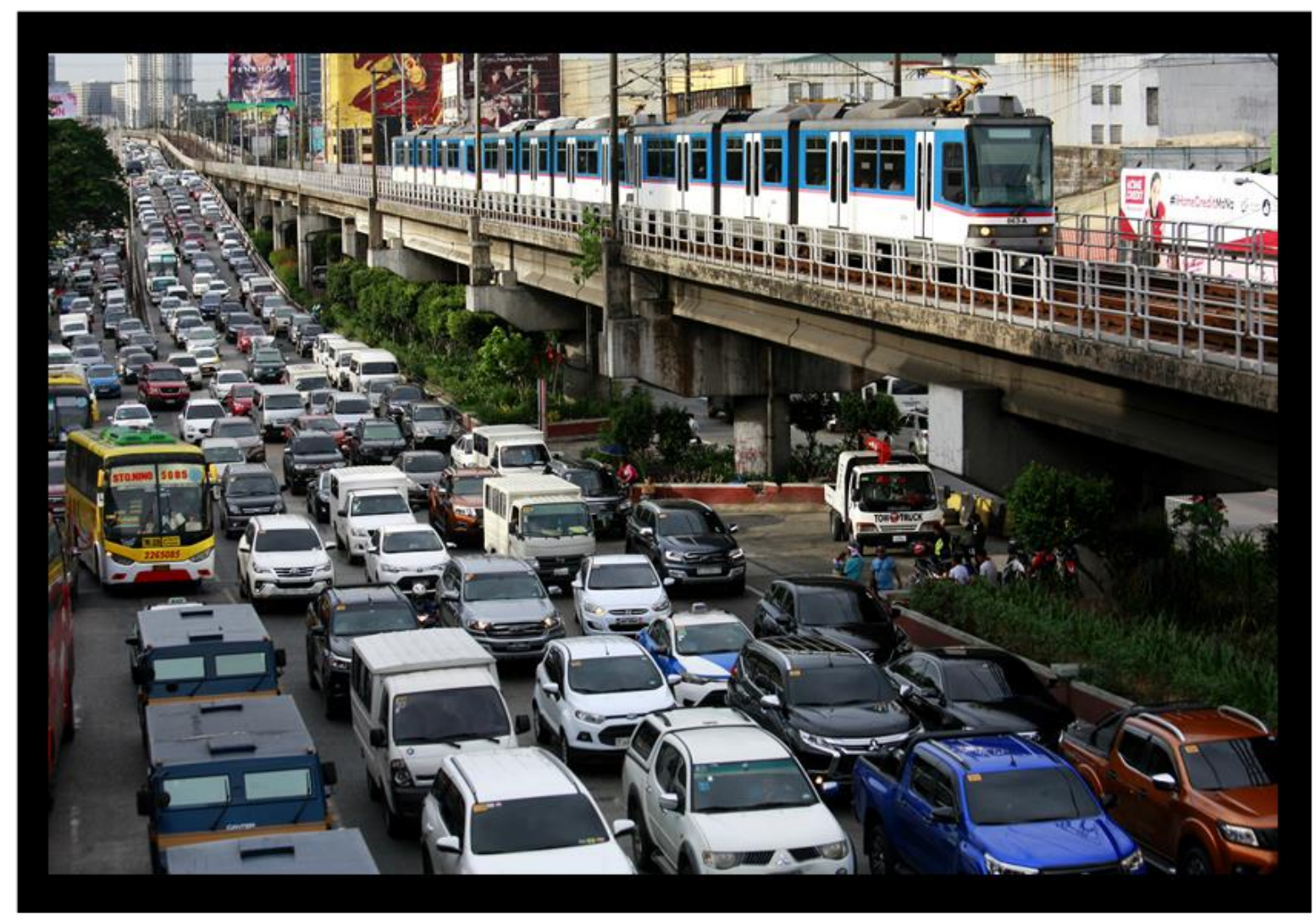

"RUSH HOUR"

Luisito Cleofas

Against this backdrop, this essay provides a critical alternative - ecological and systemic - account of traffic congestion and transportation infrastructure gridlock in Metro Manila and its suburban hinterlands. The essay draws on a rich and sophisticated body of scholarly literature which shows how transportation systems and traffic patterns are intimately and intricately interwoven with land use patterns, property taxes, and commercial retail and real-estate development, and how infrastructure investments in highways and roads, macroeconomic trends, and micro-financial incentives combine to determine levels of motorization (i.e. purchase and use of automobiles and/or motorcycles) vis-à-vis reliance on various forms of public transportation. The management of urban transportation systems and traffic flows through public investment, regulation, and planning, scholars have shown, is also profoundly shaped by the configurations and capacities of institutions of governance and by competition and contestation in the realm of politics. 


\section{The Ecosystem}

Viewed from this perspective, transportation and traffic in Metro Manila can be understood to share many of the properties of ecosystems, such as complex hydraulic ecosystems like river deltas with their ever-shifting currents and flows along myriad channels of motion and activity. ${ }^{3}$ Like such ecosystems, Metro Manila transportation and traffic is populated by a multitude of different species: buses grazing for passengers like herds of elephants along major throughways of the metropolis, Metro Rail Transit (MRT) and Light Rail Transit (LRT) trains slithering in serpentine fashion along the main arteries of Epifanio de los Santos Avenue (EDSA) and Taft Avenue, motorcycle taxi drivers darting after their prey like schools of piranhas through the crowded coral reefs of the city's streets, cars plodding along like hippos and jeepneys surfacing like crocodiles in the mangrove swamps of urban congestion, pedestrians ambling like colonies of penguins towards jeepney, bus, and MRT/LRT terminals, and, from a bird's eye view, streams of commuters slowly flowing, like upstream-bound schools of salmon, through the waterways of the metropolis. Like their metaphorical river delta counterparts, these different species of urban transportation coexist, combine in complex forms of co-dependency, and compete for scarce resources - e.g. passengers and space - on the roads and streets of Metro Manila and its suburban hinterlands.

Like such a unified, if densely and multifariously populated, eco-system, moreover, transportation and traffic in Metro Manila and its suburban hinterlands is situated within a broader macro-ecological context and susceptible to various forms of environmental change. For example, along with demographic and economic growth over the years has come motorization, with automobile sales averaging more than 400,000 per annum across the Philippines by the 2010s. The increasing flow of commuters has been accompanied by this rising tide of privately owned cars filling the urban and suburban roadways of the country's

\footnotetext{
${ }^{3}$ For the somewhat similar conception of a 'regime of congestion', see: Gopakumar 2020.
} 
metropoles and the neighboring provinces in their immediate hinterlands. Meanwhile, the multiplicity of so-called "veto players"4 within the highly fragmented and often factionalized institutional arrangements for public investment and regulation in transportation in the Philippines has made for repeated policy logjams and derailments, producing recurring spikes in congestion and diversions of traffic flows into new patterns of circulation. With the political earthquakes of the 2010 and 2016 presidential elections, moreover, have come aftershocks with palpable consequences for Metro Manila's transportation system: dramatic fluctuations in the fortunes of various road construction projects, the regularity, reliability, and capacity of MRT service along EDSA, the pace of new LRT and MRT rail extension, and policies and practices regarding buses, jeepneys, motorcycles, and other vehicles. With the onset of the COVID-19 crisis and the imposition of an Enhanced Community Quarantine (ECQ) across Luzon in midMarch 2020, traffic flows across Metro Manila dramatically thinned, however temporarily, as lockdown at home replaced gridlock on the roads and streets of the National Capital Region.

As with river delta ecosystems, the fate of one species is intimately intertwined with that of another, not only through the inter-modality of transportation, but also through competition for grazing space and the sustenance provided by passengers. Delays and derailments shift LRT and/or MRT passengers onto buses and jeepneys, while private cars crowd out public utility vehicles on the roads. Overcrowding on buses and rail lines reinforces prejudices against public transportation and preferences for private cars among those who can afford them, reproducing more gridlock. As with a hydraulic system, blockages along existing channels of movement produce surging flows and floods along others, and the creation of new throughways may exacerbate rather than alleviate traffic congestion, by increasing the volume rather than the velocity of circulation.

\footnotetext{
${ }^{4}$ Tsebelis 2002.
} 


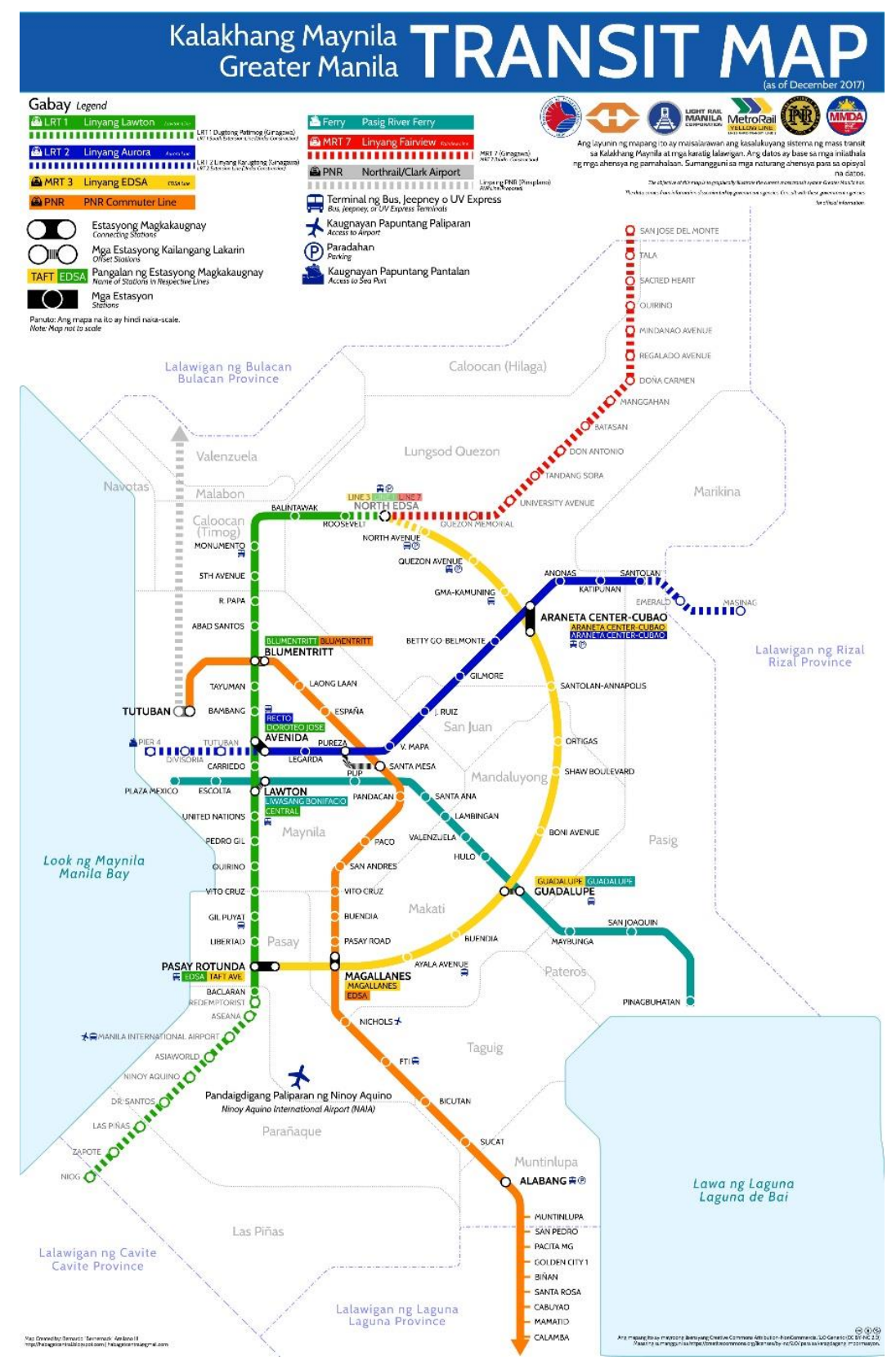

Greater Manila Transit Map

Bernardo Arellano III

This ecosystem is embedded within a broader environment of oligarchical democracy in the Philippines. On the one hand, the urban transportation system and the problems of traffic congestion must be understood in terms of the natural tendencies towards monopoly and oligopoly inherent in the transport sector, the cartel-like structures governing private transport operations and infrastructure investment, the interlocking directorate of business and banking interests benefiting from over-reliance on private automobiles, and the accumulated impact of 
decades of systematic under-investment in public transportation alongside effective subsidizing of automobile traffic through road and highway construction in and around Metro Manila and across the country. This system has served the interests not only of the diversified local conglomerates which dominate the commanding heights of the Philippine economy but also the foreign (especially Japanese) producers of the automobiles (and, to a much lesser extent, the motorcycles) which clog the streets and roads of the National Capital Region.

On the other hand, Metro Manila's urban transportation system and its problems of traffic congestion must also be understood in terms of the separation, division, and decentralization of government powers and prerogatives in the Philippines, the institutional weakness of the Department of Transportation (DOTr), the multiplicity of national and local government agencies involved in regulating transport and traffic, and the related difficulties of achieving and maintaining clarity, coherence, consistency, and coordination in government policies related to urban transport and traffic. Traffic circulation - and congestion - in Metro Manila and other major cities in the Philippines produces not only regular flows of monopoly rents accruing to the private holders of various transport franchises and concessions, but also steady streams of petty protection rents extorted by officials in the diverse regulatory and lawenforcement agencies of the national government and local government units in the national capital region and beyond. The Land Transportation Franchising and Regulatory Board (LTFRB) and the Land Transportation Office (LTO) operate as protection rackets rather than as government providers of public regulation.

At the same time, however, the ecosystem of urban transportation and traffic in Metro Manila and other major Philippine cities is also embedded within processes of demographic, economic, political, social, and technological "climate change." The economic and political costs of increased traffic congestion have stimulated unprecedented pressures for public investment in urban - above-ground and underground - rail systems in Metro Manila, private 
entrepreneurial experimentation with diverse new forms of privately operated public transport (including P2P, UV Express, and transportation network vehicle services (TNVS) like Grab and Angkas), the initiation - if not effective implementation - of a public utility vehicle modernization program (PUVMP), and consideration of - if not yet full commitment to - new schemes for buses in Metro Manila, including bus rapid transit (BRT) lines on the key thoroughfares of Quezon Avenue and EDSA. Beyond the objective realities and costs of increased traffic congestion in Metro Manila and beyond, the subjective conditions of public opinion have generated unprecedented levels of media coverage, popular interest, and political debate focused on urban traffic problems and transportation policies in the Philippines.

Viewed within the context of the ecosystem of urban transportation and traffic in Metro Manila and its hinterlands, and the ever-shifting demographic, economic, social, political, and technological environment in which this eco-system is embedded, how can we understand the prospects for policy reforms which promise to ease, expedite, and enhance mobility in the National Capital Region and beyond? If urban transportation/traffic operates as a system, what kind of systemic change is possible? A brief examination of several urban transport reform initiatives - ranging from proposals for a BRT system, the legalization of motorcycle taxis, and the improvement of pedestrian walkways, to the introduction of bicycle lanes and a PUVMP program - shows the descriptive validity and analytical value of the ecological/systemic approach to understanding traffic congestion in Metro Manila sketched above. $^{5}$

\footnotetext{
${ }^{5}$ The examination of the varying fates of these transport reform initiatives below is based on a diverse range of documentary sources, media reports, and interviews with experts, officials, and company owners in the transport sector collected/conducted over a series of trips to the Philippines since 2016.
} 


\section{Transport reform advocacy groups: A new species in the ecosystem?}

One important recent development over the past decade has been the introduction of a new species - the transport reform advocacy group - to the ecosystem of transportation and traffic in Metro Manila and its suburban hinterlands. The emergence and evolution of this new species is an outgrowth or by-product of the continued expansion and upgrade of the transportation system of the National Capital Region and the resultant proliferation of new transportation and infrastructure projects as well as real-estate development schemes. These trends have expanded and enhanced the career opportunities, educational qualifications, and associational and networking activities of a growing community of transport and urban planning specialists whose credentials, creative design skills, and technical expertise are needed for ensuring government approval, financing, and implementation of the myriad ongoing and impending projects transforming the urban and suburban landscape and its transportation system. Against this backdrop, the perhaps inevitable emergence of transport reform advocacy groups like AltMobility, the Inclusive Mobility Network, Komyut, Sakay.ph and Move Metro Manila over the past few years has helped to amplify the voice and visibility of transportation experts and other public advocates for transport policy reform in the traditional media, on social media, and in dialogues with members of Congress and policymakers in the Department of Transportation (DOTr) and other local and national government agencies.

To date, the collective voice of commuters in and around Metro Manila has only been exercised through votes in elections, in a diffuse but perhaps increasingly decisive fashion. The 2016 presidential election is notable for results in which former Senator Manuel 'Mar' Roxas won a mere fourteen percent of the popular vote in Metro Manila (compared to Duterte's forty-four percent and Senator Grace Poe's twenty-one percent) despite support from the incumbent administration's machinery and the formal endorsement of key city mayors in the 
metropolis. Roxas's poor showing may have reflected the backdrop of scandals, controversies, and widespread public perceptions implicating him - as former Department of Transportation and Communications (DOTC) Secretary - in the deepening problems with the MRT-3 and increasing traffic congestion in the National Capital Region over the years leading up to the May 2016 election. ${ }^{6}$ But even this kind of collective commuter voice has remained restricted to retrospective attribution of blame for past policy mistakes and limited in terms of effective input and influence with regard to transport policy decision-making moving forward.

Against this backdrop, it might be hoped that the emergence, increasing visibility, and expanding voice of advocacy groups promoting urban transport reform could affect the existing ecosystem of transportation and traffic in Metro Manila and its hinterlands in a systemic fashion. Effective advocacy by transport experts could conceivably amplify the voice of Metro Manila's commuters and articulate expert opinions and advice, thus increasing both the sense of urgency and the effectiveness of government policymaking. Indeed, some transport reform advocates have achieved considerable access, visibility, and influence in discussions and debates about transportation and traffic, in the media, in Congress, and within the DOTr. This development could play a role in catalyzing a systemic upgrade in the political and policymaking environment in which Metro Manila's transportation system and traffic congestion problems are embedded, helping to unpack problems, unlock policy gridlocks, and unveil innovative and effective policy solutions over the months and years ahead.

How might such a holistic, environmental upgrade enable and impel concrete policy reforms and systemic change in Metro Manila's transportation system? To date, transport

\footnotetext{
${ }^{6}$ Holmes 2016, 31. Over the course of 2014-2016, maintenance problems with MRT-3 trains led to recurring disruptions and derailments which drastically affected the 17-kilometer line along the major thoroughfare of Epifanio De los Santos Avenue (EDSA). At its peak, the MRT3 was servicing more than 500,000 passengers per day, and the direct and indirect impact of disruption to the line generated considerable public outrage in the period leading up to the May 2016 election, with Roxas implicated in widely publicized accusations of DOTC incompetence, negligence, and corruption.
} 
reform advocates have mixed insider access and lobbying efforts, on the one hand, with an increasingly visible and vocal media presence in the realm of public opinion and policy debate, on the other. On both fronts there is ample evidence of impact.

But there remains a distinct possibility that the diversity of advocates, activities, points of access, and issues will enable the absorption of this new species - the transport reform advocacy group - into the pre-existing, if still evolving, current ecosystem without effecting systemic transformation. As scholars of transportation policies in other contexts have observed, expert advice and so-called evidence-based policymaking only produce systemic transformation through effective negotiation of the political process. ${ }^{7}$ Rather than operating as effective log drivers untangling logjams, today's transport reform advocates may end up being enlisted in diverse ancillary roles within the multi-stranded tributaries of urban transportation policy-making - i.e. as consultants and junior government officials - and becoming ensnarled within policy logjams themselves. To understand the actual impact of reform advocacy groups on the ecosystem of urban transport in and around Metro Manila, a close analysis of recent reform advocacy campaigns is in order.

\section{A bus rapid transit (BRT) system?}

One example of urban transport reform advocacy has been the promotion BRT system in Metro Manila, with detailed plans drawn up for BRT lines on the major thoroughfares of EDSA and Quezon Avenue. ${ }^{8}$ Here it is worth noting that proposals for a BRT system are fully in line with a consensus among urban transport experts and an established body of evidence as to the

\footnotetext{
${ }^{7}$ For a classic account, see: Flyvberg 1998.

${ }^{8}$ See, for example, Johansson 2016a; Johansson 2016b; Institute for Transportation and Development Policy/Asian Development Bank 2016a.
} 
benefits of such a reform. A BRT system with fixed stations, timetables, and automated fares would rationalize and regularize bus operations in ways which would reduce the time, space, costs, inconveniences, and discomforts associated with unregulated competition for passengers. Instead of bus drivers lurching across lanes and lingering along the road to maximize passengers and fares, a BRT system would restrict bus drivers to a single dedicated lane, a fixed schedule, and an hourly wage, thus ensuring regular, reliable, , and rapid bus travel for passengers. Objections to BRT proposals have remained very narrowly focused on possible technical glitches rather than on the BRT concept per se. As reforms go, this one is certainly technically sound and amply worth advocating, insofar as the demonstrably positive - indeed transformative - impact on major conurbations in other countries suggests the possibility of a meaningful impact on transportation patterns and traffic flows in Metro Manila. ${ }^{9}$

But urban transport reform advocacy groups' efforts to promote a BRT system in Metro Manila have run up against a set of stubborn political obstacles. To date the DOTr has been strikingly ambivalent and ambiguous in terms of its actual support for BRT projects, despite the formal approval of the BRT scheme by the National Economic and Development Authority (NEDA) and the availability - and actual allocation - of funding from the national government and overseas development agencies. The Department's stance on the BRT issue has been interpreted by observers as reflecting the domestic political toxicity of the BRT brand because of its association with former Cebu City Mayor Tomas “Tommy" Osmeña, an opponent of President Duterte, as well as the personal skepticism of DOTr Secretary Arthur Tugade with regard to the actual impact and potential effectiveness of a BRT system for reducing traffic congestion. ${ }^{10}$

\footnotetext{
${ }^{9}$ Barry and Kaenzig 2019.

${ }^{10}$ See, for example, Valdez 2018.
} 
But DOTr's evident unwillingness to implement a BRT system should also be understood in the context of the broader urban transportation ecosystem and in particular the forms of symbiosis and synergy observable between the two major BRT projects slated for Metro Manila and the national capital region's light rail transit lines. Here it is worth noting perceptions of rivalry - rather than complementarity - between the MRT-3 line and the proposed BRT line along EDSA, as well as potential competition over both space and passengers between a BRT line and a proposed LRT line along Quezon Avenue. Such perceptions are especially significant insofar as they may prejudice powerful interests invested in light rail projects in Metro Manila and pit them against BRT projects behind the scenes at DOTr and in Congress, if not publicly. The San Miguel Corporation's unsolicited proposal for a new elevated toll road on EDSA may also impact the prospects for a BRT line along the same thoroughfare, especially if the proposal includes BRT lanes in its design. ${ }^{11}$

More generally, prospects for the development of a broader BRT system must be seen as intimately intertwined with - and impeded by - the strikingly slow evolution of light transit and subway lines across Metro Manila. On EDSA, the MRT-3 line has remained plagued by recurring accidents and reduced service related to protracted technical and legal difficulties with the renewal of its stock of trains. The future of the MRT-3 is also unclear, as seen in the appearance and disappearance of a string of proposals for a new operator to replace the existing partnership between the DOTr and a consortium of business interests, which is due to expire by 2025. Beyond EDSA, various projects for new LRT and MRT lines and line extensions have likewise proceeded at a snail's pace, for reasons which remain less than fully clear. Perhaps, as is often suggested, these projects have experienced delays and other difficulties simply due to right of way (ROW) issues, and the owner-operators of these concessions are genuinely keen to move forward with the construction and opening of new lines but have been thwarted by

${ }^{11}$ Valdez 2019. 
local residents, their legal and political representatives, bureaucratic red tape, and restraining orders issued by the courts. But perhaps these light rail transit line projects have also been delayed for other reasons, such as the greater advantages accruing to the operators if they defer construction until market conditions - and properly synchronized intermodal transport linkages - guarantee more reliable returns on their investments. ${ }^{12}$

After all, these rail interests include leading diversified conglomerates such as the Ayala Corporation and the Metro Pacific Group of companies, whose interests in major public utilities (i.e. electricity and water), real-estate holdings, retail outlets, and highway toll concessions may conflict with speedier progress on the extension of Metro Manila's light rail transit system and the establishment of a BRT system. Through cartelized ownership and/or operation of the key arteries of Metro Manila - its toll roads and light transit lines, its electricity grid and water system, and its telecommunications infrastructure - these conglomerates extract significant daily rents from residents and commuters. Within this broader context, perhaps a BRT system is only politically imaginable if it too were to operate as yet another private monopoly concession rather than as a genuinely public service. ${ }^{13}$

\section{Liberalization and deregulation?}

Alongside a BRT system, urban transport reform advocacy groups have also rallied behind an additional set of policy reforms involving the liberalization, deregulation, and/or legalization of various other forms of vehicular traffic providing public transport on the streets and roads of Metro Manila. Such options include the lifting of number coding restrictions for public utility vehicles imposed by the Metro Manila Development Authority (MMDA) in 1995, the

\footnotetext{
${ }^{12}$ For background on the LRT1 Extension, for example, see Amojelar 2016.

${ }^{13}$ Gutierrez and Rodriguez 2013; Tiglao 2016.
} 
easing of barriers to entry into the premium P2P (Point-to-Point) bus service market, and the legalization of motorcycle taxis. Each one of these reforms has been under consideration by the DOTr and other government agencies responsible for overseeing transport and traffic. But each has encountered obstacles to introduction and implementation.

In the case of MMDA's number coding restrictions for buses and jeepneys, for example, urban transport reform advocates have once again made a strong case for a seemingly selfevidently sensible reform. ${ }^{14}$ Such restrictions - keeping vehicles off the roads one day a week based on license plate numbers - are assumed to have contributed to a twenty percent reduction in the number of jeepneys and buses on the roads and streets of the National Capital Region. ${ }^{15}$ This reduction, it is further argued, has led to shortages of public utility vehicles, queueing at jeepney and bus terminals, long curb-side waits for passengers, needless crowding at transport chokepoints, and protracted delays for commuters unable to begin their already slow-moving daily journeys in a timely fashion. These restrictions have further contributed to the conditions encouraging purchase and use of private automobiles or motorcycles, thus exacerbating the underlying pattern of excessive private vehicular traffic which causes traffic congestion in and around Metro Manila. There appears to be some empirical evidence in support of this understanding of the problem as well as an intuitive supply-and-demand logic to the proposed solution. ${ }^{16}$

That said, some fundamental puzzles remain as to the current system of number coding in terms of how it actually operates, the interests that it serves, and the obstacles it throws in the path of effective reform advocacy. For example, if the current system is so inefficient and needlessly idles hundreds if not thousands of jeepneys and buses every day of the working

\footnotetext{
${ }^{14}$ Chanco 2019a.

${ }^{15}$ Metro Manila Development Authority 1995.

${ }^{16}$ Siy 2015.
} 
week, then why do some other studies report low levels of average passenger use of buses and jeepneys during many hours of the day? ${ }^{17}$ If the current system is so clearly disadvantageous to owners of jeepneys and buses, then why have they not clamoured for removal of restrictions for public utility vehicles over the years, and why are they so remarkably inactive on this front today? If the current system is so obviously flawed and deleterious in its impact, then why have reform advocates encountered such a curious mixture of acknowledgement of the merits of reform on the one hand, and persistent lack of interest in implementing reform on the other? Why has the call for the lifting of number coding for buses and jeepneys encountered little in the way of open defence of the current system but also little in the way of overt opposition to it?

Answers to these puzzling questions lie in a closer analysis of how number coding restrictions on public utility vehicles actually operate, the interests which these restrictions serve, and the actual impact they have on public utility vehicle traffic in Metro Manila and its suburban hinterlands. After all, it is common knowledge that jeepney and bus owners and operators have made special arrangements with the Land Transportation Office (LTO) and/or the Land Transportation Franchising and Regulatory Board (LTFRB) which allow them to sidestep number coding restrictions. ${ }^{18}$ Here it is also be worth noting the reportedly impressive extent of the MMDA's reliance on unofficial revenues collected through the enforcement of the number coding restrictions on jeepneys and buses. ${ }^{19}$ The actual franchising system - and the number coding restriction scheme - operate according to a logic neither entirely unrelated to, nor wholly identical with, the official rules and regulations imposed and enforced - or at

\footnotetext{
${ }^{17}$ Chanco 2019b; Domingo, Briones, and Gundaya 2015.

${ }^{18}$ Elemia 2015a; Elemia 2015b.

${ }^{19}$ Avecilla 2014
} 
least in principle enforceable - by the MMDA and other government agencies. ${ }^{20}$ In other words, a secondary market in license plate numbers, surreptitious subcontracting in bus and jeepney franchise operations (the so-called kabit - i.e. mistress - system), and "protection fee" payments to MMDA and other enforcement officers may well be at work, as knowledgeable insiders are quick to suggest. ${ }^{21}$

Viewed from this perspective, these puzzles concerning the number coding restrictions should be understood in terms of an underlying ecosystem and equilibrium model governed by a mix of market incentives derived from urban transportation flows and rents derived from the franchising and regulatory agencies of the national and local government units overseeing these transportation flows in the National Capital Region. A shift in the rules governing the available supply of jeepneys and buses on the major roads of Metro Manila, and in the regulatory powers of the MMDA and other traffic enforcement agencies over flows of jeepneys and buses over these roads, might not simply lead to enhanced supply of jeepneys and buses in line with commuter demand but other unanticipated outcomes instead. As for the prospects for such a shift in the first place, the self-sustaining ecosystem operating around MMDA's number coding restrictions is sufficiently robust in its rude health as to resist reform for the foreseeable future.

Meanwhile, urban transport reform advocates have also focused their energies on the easing of barriers to entry into the $\mathrm{P} 2 \mathrm{P}$ bus service market, which provides non-stop, airconditioned bus rides from shopping centers and other transport hubs in Metro Manila to and from local nodal points in the suburbs. They have urged the Land Transportation Franchising and Regulatory Board (LTFRB) to loosen some of the restrictions on P2P franchises issued in

\footnotetext{
${ }^{20}$ Real 2010.

${ }^{21}$ For background, see: Domingo, Briones, and Gundaya 2015. The Supreme Court has defined the kabit system as "an arrangement whereby a person who has been granted a certificate of convenience allows another person who owns motor vehicles to operate under such franchise for a fee."
} 
2015 and 2017, during the period when these bespoke bus services were first introduced. Liberalization would open P2P franchises to unsolicited applications for existing or new routes, allow for smaller capacity buses and smaller fleets, enable competition on P2P routes between rival operators, and leave discretion over fare-setting in the hands of $\mathrm{P} 2 \mathrm{P}$ operators. These proposed reforms thus promise a potentially transformative liberalization of this niche form of public transport which could enable existing owner-operators and new entrants to expand their investments and thus increase the supply of P2P buses connecting Metro Manila and its suburban hinterlands.

Urban transport reform advocates' focus on P2P buses makes ample sense within the broader eco-system of transportation and traffic in Metro Manila and its suburban hinterlands. P2P buses represent a very important transport sub-species within this ecosystem, insofar as their premium service - comfortable, reliable, safe travel between up-market residential and commercial points - is more likely than any other mode of public transport to attract commuters who would otherwise clog roads and streets with private cars. Yet some research suggests that P2P bus services have experienced only limited growth since they first emerged in 2015, leading reform advocacy groups to suspect that market expansion is being hindered by excessively restrictive regulation and franchising.

At the same time, however, perhaps the broader ecosystem itself is impeding P2P growth. After all, owner-operators of $\mathrm{P} 2 \mathrm{P}$ bus services are privately willing to acknowledge the sizeable obstacles to entry, expansion, and profitability in this particular niche market within the region's broader transport ecosystem. ${ }^{22}$ The systemic problems of traffic congestion limit the profitability of $\mathrm{P} 2 \mathrm{P}$ bus services and thus inhibit further investment and expansion of P2P fleets, routes, and passengers. The challenges of transport inter-modality also loom large, as the "first mile" and "last mile" of commuters" journeys beyond the two points covered by

\footnotetext{
${ }^{22}$ Interviews with two different P2P bus company owners, 9 September 2019.
} 
P2P services impede the attraction of more car-purchasing/-owning/-riding commuters to premium buses shuttling between their areas of residence and employment. Some P2P service owner-operators suggest that there might be opportunities for linkage with transportation network vehicle service (TNVS) providers. Others even suggest that companies may already be exploring such possible linkages. In other words, it is possible that the primary obstacles to growth in P2P bus services and passenger traffic lie not in the restrictions imposed on routes and franchises by the LTFRB, but elsewhere within the complex ecosystem of urban and suburban transportation and traffic in Metro Manila and its hinterlands. Insofar as this is the case, then an easing of the formal restrictions on $\mathrm{P} 2 \mathrm{P}$ franchises may not produce the anticipated result of expanding supply, given the relative inelasticity of demand.

In addition, owner-operators of $\mathrm{P} 2 \mathrm{P}$ bus services also privately acknowledge the considerable ambiguities and inconsistencies which are evident in the actual operations of the LTFRB's current system for awarding franchises and routes for P2P bus services. ${ }^{23}$ There appears to be evidence of favoritism towards established bus companies, whose owners benefit from many years of experience with and privileged access to the LTFRB. There also are anomalies in the procedures and criteria governing the awarding of franchises and routes. In other words, as with buses and jeepneys, the actual franchising system for P2Ps operates in ways which inhibit entry and expansion by some players while enabling flexible operations by other players, but not in strict accordance with the provisions of the LTFRB departmental orders of 2015 and 2017. Insofar as this is the case, the proposed easing formal restrictions on the awarding of P2P franchises and routes may not have the desired effect and impact of actually changing the actual rules of the game.

Finally, urban transport reform advocates have also been calling for the legalization of motorcycle taxis in Metro Manila and beyond. These reform advocates reason that the rising

\footnotetext{
${ }^{23}$ Interviews with two P2P bus company owners, September 9, 2019.
} 
demand for such services over the past several years has rendered widespread illegal operations essentially inevitable and irrepressible, and that decriminalization could provide significant benefits in terms of greater safety, reliability, and quality of service provision, with legalization and regulation encouraging stronger qualifications, training, insurance coverage, and legal liability for motorcycle drivers and taxi service providers. They also reason that the legalization of motorcycle taxis in Manila and beyond would allow for the expansion of motorcycle taxi passenger traffic in ways which would supplement and synergize with other modes of transport, at least in the short and medium term. As suggested above with reference to $\mathrm{P} 2 \mathrm{P}$ bus services, for example, enhanced motorcycle taxi service provision could conceivably enable increased demand for $\mathrm{P} 2 \mathrm{P}$ bus services and thus assist in weaning more commuters away from private car ownership and usage. The expansion and enhancement of motorcycle taxi services could further reduce reliance on automobile taxi services and automobile-based TNVS, most notably the Singapore-based company Grab (the dominant player in the market), thus further contributing to reductions in private automobile traffic and traffic congestion in Metro Manila and beyond.

Interestingly, urban transport reform advocates have made more progress on the legalization of motorcycle taxis than on any other proposal on their agenda, even in the face of continued resistance on the part of DOTr Secretary Tugade. In November 2017, the LTFRB suspended the operations of the motorcycle taxi company Angkas, but this decision was partially reversed by DOTr in mid-2019. A six-month pilot run was launched, limited to 27,000 Angkas drivers, with a technical working group set up to evaluate road safety and service, even as a raft of new bills were filed in Congress calling legalization of motorcycle taxis and introduction of a new regulatory framework for their operations in Metro Manila and other major Philippine cities. ${ }^{24}$ For the time being, Angkas was effectively granted a monopoly on

\footnotetext{
${ }^{24}$ Department of Transportation 2019.
} 
legal motorcycle taxi operations in Metro Manila, albeit one which capped the number of drivers (and thus limited expansion) and left the company reliant on government enforcement to close down various fly-by-night unlicensed operators of rival services which repeatedly popped up on the Internet over the latter half of 2019.

In January 2020, however, the previously anticipated three-month extension of Angkas's short-term monopoly was suddenly modified. Two new service providers, JoyRide and Move It, were included in a three-month extension of the pilot scheme, with each of the three firms capped at 15,000 motorcycle taxi drivers across Metro Manila. The inclusion of JoyRide was met with considerable speculation as to the actual ownership and political affiliation of the company, with initial rumors suggesting that newly elected Senator Bong Go, a long-time personal assistant to President Rodrigo Duterte and former head of the Presidential Management Staff in from 2016 to 2018, had a personal stake. Senator Aquilino "Koko" Pimentel III, another close Duterte ally, also was singled out for intervening to promote the interests of the firm. While these rumors and speculation generated a chorus of denials from both the two senators and JoyRide executives, it was eventually revealed that Ralph Nubla, a banker best known for his role as a business intermediary for former President Ferdinand Marcos (1966-1986), is a major shareholder. ${ }^{25}$

As of this writing, the operations of these three motorcycle taxi services have been suspended due to the COVID-19 pandemic and the enhanced community quarantine (ECQ) imposed by the Philippine government in March 2020, with drivers diverted to food delivery services until passenger rides are allowed to resume. Meanwhile, the legalization of motorcycle taxis remains under consideration, both within DOTr and in Congress. But for the time being, and perhaps for the foreseeable future, a triopoly has emerged under an irregular

\footnotetext{
${ }^{25}$ Madarang 2020. Marcos' son, Ferdinand "Bongbong" Marcos, served as a senator from 2010 to 2016 before running as Duterte's vice-presidential running mate in 2016, and his daughter, Imee Marcos, was elected to the Senate in 2019.
} 
and insecure set of franchising arrangements under the discretion of DOTr, the LTFRB, and key legislators affiliated with the Duterte Administration. Of all the proposals for liberalization and deregulation promoted by urban transport reform advocacy groups, it is perhaps unsurprising and instructive that it is only the legalization of motorcycle taxis which has moved forward, albeit only into a protracted legal and regulatory limbo within which new cartel-like arrangements and old problems of rent-seeking and regulatory capture are amply apparent.

\section{Micro-mobility?}

Beyond these proposals to ease and accelerate flows of vehicular traffic through the introduction of a BRT system and selective liberalization and deregulation of jeepney, bus, P2P, and motorcycle taxi services across Metro Manila, transport reform advocacy groups have also focused considerable attention and energy on initiatives in the realm of what they term micro-mobility, in order to enable and encourage more travel within the National Capital Region by bicycle and by foot. For these transport reform advocates, cycling and walking are crucial complements to the proposed reorganization of vehicular transportation across Metro Manila and neighboring provinces, providing appealingly eco-friendly solutions to the problems of the 'first mile' and 'last mile' of commuters' daily journeys by public transport, and promoting a reconceptualization and reconfiguration of urban and suburban streets in which people rather than automobiles are accorded priority.

Against this backdrop, over the past several years transport reform advocacy groups have been waging a multi-pronged campaign to expand bicycle lanes, sidewalks, and pedestrian walkways. Their vision is similar to the Metro Manila Greenways project conceived by the New York-based Institute for Transportation and Development Policy, which envisages the creation of an eco-friendly network of corridors for non-motorized transport 
connecting core areas of the metropolis. ${ }^{26}$ To this end, local government agencies and mayors have been lobbied, especially in cities like Pasig where the chief transport planner, Anton Siy, is a leading reform advocate with a special interest in micro-mobility. At the same time, senior officials within the Department of Public Works and Highways have also been approached and encouraged to consider procedural reforms which might enable if not ensure the institutionalization of new operating procedures and budgetary allocations at the national government level for the inclusion of bike lanes and sidewalks in road construction projects in Metro Manila and other cities across the Philippines.

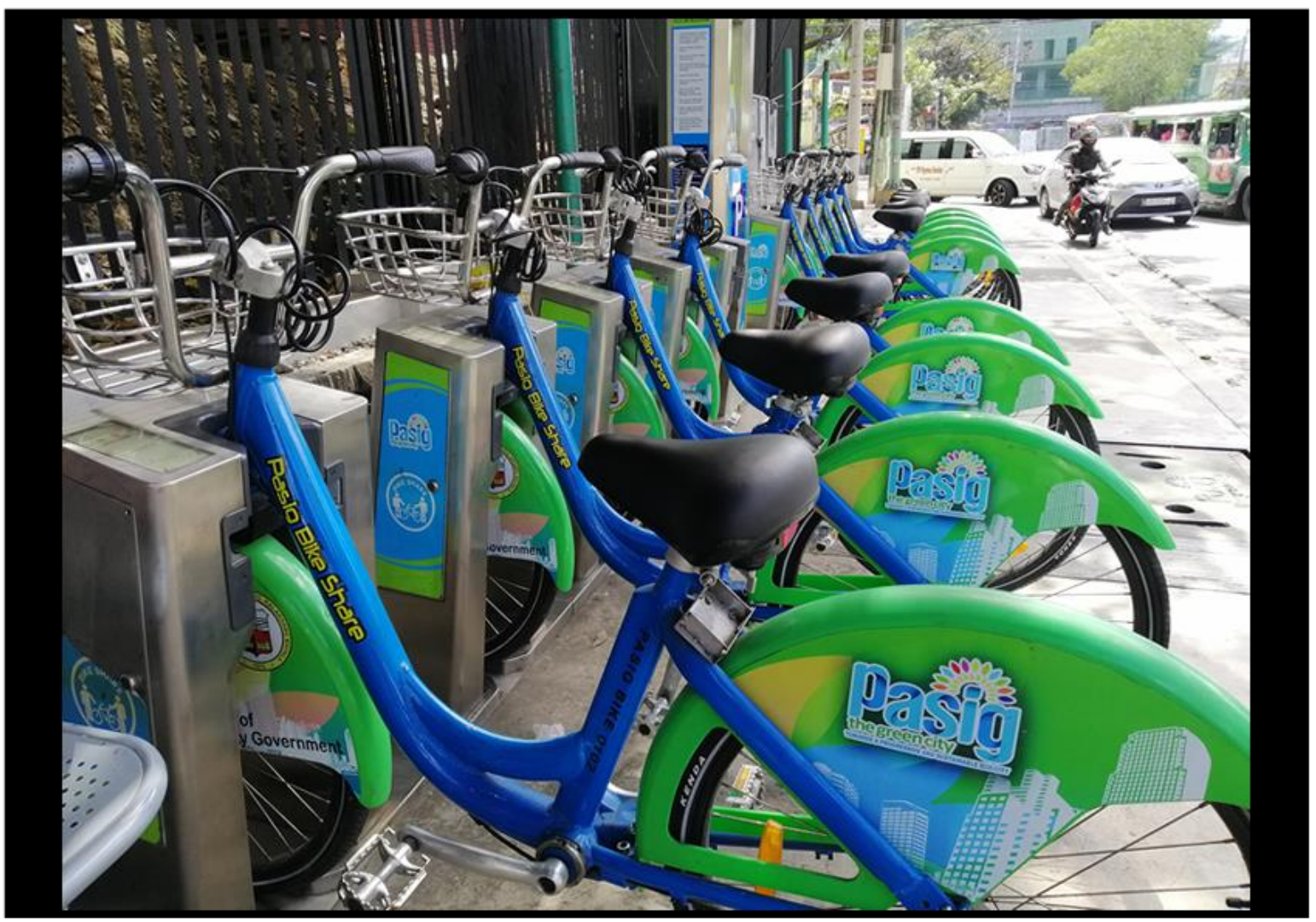

GRAB A BIKE

Gecerein Sayen Ocampo

${ }^{26}$ Institute for Transportation and Development Policy/Asian Development Bank 2016b. 
To date, these efforts have produced only limited progress on the micro-mobility front in the face of the obstacles presented by the accumulated interests invested in the existing automobile-centered ecosystem and the established landscape of streets and roads. It is worth noting the close and complex connections between land-use patterns, property taxes, real-estate development, social inequalities, parking, and various kinds of transport flows. The ecosystem in Metro Manila and its suburban hinterlands is organized around and dominated by private vehicular traffic, with the automobile as its dominant species. Thus the changes necessary for the easing, enhancement, and expansion of pedestrian and bicycle traffic flows go far beyond the challenges of installing bike lanes and improving and expanding sidewalks across areas of the metropolis or establishing new procedures for roadworks projects at DPWH.

After all, as evident in the Metro Manila Greenways proposal, urban transport reform advocates' plans for the installation of bicycle lanes and the improvement and expansion of pedestrian walkways are most fully developed in certain kinds of contexts within the vast and diverse landscape of the National Capital Region. The Greenways proposal focuses on the cities of Makati, Mandaluyong, Pasig, and Taguig, with the up-market business, commercial, and residential districts of Makati City, the Bonifacio Global City (BGC), and the Ortigas Center the core nodal areas within which existing high-quality pedestrian facilities and appetites for walking, jogging, and cycling are most fully developed. Yet even in these areas the prevalence of private automobile ownership among high-end residents, commuters, and shoppers places a premium on road space and parking spaces that restricts the possibilities for the installation of new bicycle lanes and expanded walkways. As in the elite residential subdivisions and shopping areas found elsewhere in and around Metro Manila, private realestate development has proceeded according to designs in which automobiles are accommodated at the expense of the pedestrians, cyclists, and public utility vehicle passengers, as seen in tight restrictions on bus and jeepney routes (which serve the low-paid 
workers servicing these up-market areas). Strolling and cycling for pleasure could be appealing options and atmospheric accoutrements of a privileged lifestyle in such settings, with safety, sanitation, and security set at standards resembling those found in, say, southern California. But real estate and retail interests work against the opening of these sheltered enclaves to freer flows of passengers, pedestrians, or cyclists from beyond this socio-economic 'bubble', as urban transport reform advocates envisage through the introduction of a BRT system and the other reforms discussed above. ${ }^{27}$

Meanwhile, prospects for the improvement and expansion of walkways and the installation of bicycle elsewhere across Metro Manila and its neighboring suburban provinces lanes have been restricted by other kinds of constraints in the built environment and the broader transport eco-system. ${ }^{28}$ After all, in the densely latticed patchwork of residential and commercial areas catering to various social tiers of the broad mass of the population of the metropolis and adjacent suburban provinces, existing pressures on streets and roads have been intensifying with every passing year. Beyond the bus and jeepney routes coursing through major roads and thoroughfares, a growing number of cars and motorcycles are clogging the side streets and would-be shortcuts of Metro Manila.

For those unable to afford the luxury of private automobile or motorcycle ownership, moreover, fleets of tricycles - motorcycles with covered sidecars - cluster in and around major shopping centers and connections to jeepney, bus, and rail lines, further cluttering the streets with slow moving, low-volume, and high-polluting vehicular traffic. Servicing a broad swathe of the local population, producing a steady stream of formal and informal operating fees which bolster local government coffers, and providing low-income employment to thousands of drivers, these tricycles constitute an additional alternative and impediment to the

\footnotetext{
${ }^{27}$ Galingan, Alcazaren, Ramos, and Santos 2009; Boquet 2019.

${ }^{28}$ Mateo-Babiano 2016.
} 
expansion and institutionalization of corridors for pedestrian and bicycle traffic. ${ }^{29}$ Thus transport reform advocates' proposals for more efficient, equitable, and eco-friendly forms of micro-mobility have continued to run up against the accumulated built environment, the established everyday practices of commuters and drivers, and the entrenched retail, real-estate, small-scale transport, and local political interests embedded in Metro Manila's private automobile-centered transport eco-system.

\section{Reform without reformists: the public utility vehicle modernization program (PUVMP)}

If transport reform advocacy groups have faced seemingly insurmountable obstacles to the introduction and implementation of these diverse reform proposals, then what about the prospects for other reforms initiated by the Philippine government? After all, President Rodrigo Duterte was elected in 2016 against a backdrop of widespread public dissatisfaction with the preceding Aquino administration's mishandling of transport policies, and in the context of his own perceived potential - and repeatedly expressed promises - for more decisive and effective action on this front. Indeed, alongside the President's infamous War on Drugs and flirtation with China, a defining feature of the Duterte administration since its inauguration has been its aggressive pursuit of transportation and infrastructure development, embodied in the program, "Build Build Build."

While President Duterte and DOTr Secretary Tugade failed to secure emergency powers from Congress to address traffic congestion in Metro Manila despite persistent efforts on this front over the first three years of his six-year presidential term, his administration embarked on an ambitious public utility vehicle modernization program (PUVMP) in mid2017. Modelled after a project introduced with Asian Development Bank (ADB) support in

${ }^{29}$ Talampas 2017. 
Davao City when Duterte served as mayor (2013-2016), the PUVMP focused on the reorganization and rationalization of jeepney traffic across the Philippines, with a focus on major conurbations like Metro Manila. The impetus and imperative for this program was twofold. On the one hand, the PUVMP was designed to replace aging, unsafe, overly cramped, diesel-fuelled, smoke-belching jeepneys with new, larger, state-of-the-art, eco-friendly vehicles with engines compliant with Euro 4 emission standards and higher carrying capacity, providing safer, more comfortable, efficient, and environmentally sound travel for higher numbers of passengers. ${ }^{30}$

On the other hand, the PUVMP was also designed to shift jeepney operations from the boundary system in favour of more efficient route management to eliminate driver incentives for frequent lane-changing, stopping, and idling. To this end, the new vehicles would be kitted out with CCTV cameras and GPS monitors, fire extinguishers, automated fare collection systems, front-facing seats, and new right-hand-side minibus-style doors for more orderly curbside passenger embarkations and disembarkations at designated stops. These two aims corresponded to transport experts' arguments and evidence indicating that the existing fleet of jeepneys and the established system of jeepney operations significantly contributed to pollution and traffic congestion in Metro Manila and other major conurbations in the Philippines. ${ }^{31}$

Against this backdrop, the PUVMP began with a two-pronged strategy for implementation over a three to four-year period. The DOTr and attached agencies like the Land Transportation Franchising and Regulatory Board (LTFRB) imposed a timetable for the mandatory phasing out of old jeepneys and the introduction of new vehicles. These replacements must follow guidelines and standards that are designed to encourage the local manufacture. In addition, purchases are to be subsidized by the government-run Land Bank of

\footnotetext{
${ }^{30}$ Biona, Mejia, Tacderas, dela Cruz, Dematera and Romero, 2017.

${ }^{31}$ Mettke, Guillen, and Villaraza 2016.
} 
the Philippines (LBP) and Development Bank of the Philippines (DBP). In addition, new franchising guidelines were issued, phasing out established PUV routes and franchises and stipulating that bids for new routes and franchises can only be made by cooperatives or companies (rather than individuals) able not only to purchase and operate a fleet of new vehicles as per PUVMP standards, but also to establish and maintain a garage and terminal for the vehicles and a system for management of timetabled PUV operations and drivers working for hourly wages. ${ }^{32}$

Two underlying - if publicly underplayed - elements of the PUV Modernization Program design are especially worthy of note. Although the program ostensibly encouraged and enabled jeepney drivers to work together to form cooperatives to purchase fleets of new vehicles and bid on new routes and franchises, the size and terms of the loans provided by the LBP and the DBP did not actually suffice to do so. In fact, the consolidation of PUV ownership and operations was quietly anticipated to unfold through a shift not only to larger, new-fangled vehicles, but also through a shift from jeepneys to buses on many routes. Thus PUV consolidation favored companies with the capital and the connections needed to secure financing and the franchises needed for the new economies of scale, whether bus companies interested in expansion or companies already experimenting with and investing in new kinds of jeepneys. Such companies reportedly often included former DOTr and LTFRB officials on their boards or serving as intermediaries in their communications and consultations with these government agencies, as did many companies working to secure government approval for the production design for new vehicles. ${ }^{33}$

32 Department of Transportation (DOTr) 2017; Land Transportation Franchising and Regulatory Board (LTFRB) 2018.

${ }^{33}$ Interview with owner of jeepney company, 18 April 2018. 
In addition, implementation of the program also entailed complex and cumbersome procedures for the reorganization of PUV routes and franchises. Across the country, local governments were tasked with the formulation of local public transport route plans (LPTRPs) for new routes and franchises, subject to the approval of the LTFRB, with the DOTr contracting out the drafting of a plan to cover the sixteen cities and one municipality of Metro Manila. ${ }^{34}$ This elaborate exercise in transport planning was to precede the opening of new routes and franchises to bidding and the evaluation of bids by the LTFRB. In other words, not only were public utility vehicles to be modernized and PUV ownership and management consolidated, the entire system of PUV routes and franchises was to be reorganized.

In this context, the most puzzling and problematic feature of the PUVMP's design was the complex and cumbersome procedures for the reconfiguration of the entire system of franchises and routes to be overseen by the LTFRB. Neither the official aims of the PUVMP nor the underlying problems cited as justification for the program included any reference to the existing network of jeepney routes or the system of franchising under the LTFRB. None of the studies undertaken in conjunction with the PUVMP and nothing produced by the DOTr or the LTFRB in connection with the program suggested that there was a mismatch between the current supply of and passenger demand for jeepney vehicles, or that there were structural inefficiencies in the jeepney market impeding its effective meeting of passenger demand for vehicle supply in the foreseeable future. Instead, the problems were assumed to be the current aging, smoke-belching jeepneys and the perverse incentives responsible for congestionenhancing jeepney driver behaviour. The ostensible rationale for modernization, it appears, had nothing to do with the routes themselves.

\footnotetext{
${ }^{34}$ Department of Transportation, Department of the Interior and Local Government, and Land Transportation Franchising and Regulatory Board 2017.
} 
Against this backdrop, the implementation of the PUVMP clearly has bogged down over the three years since its inception, with very few new-fangled vehicles operating on new PUV routes and franchises in Metro Manila or elsewhere across the Philippines. ${ }^{35}$ The apparent failure of this ambitious government initiative is evidence of the seemingly insurmountable obstacles to top-down reorganization or reform presented by the accumulated interests and practices associated with jeepney traffic within the ecosystem of urban transport in Metro Manila. After all, with an estimated 180,000 to 250,000 jeepneys on the road nationwide, perhaps a quarter of which operate in Metro Manila, thousands of livelihoods and the established commuting routines of millions of citizens have been jeopardized by the PUVMP. Jeepney traffic accounts for more than seventy-four million passenger kilometers in Metro Manila per year and around one-half of all peak-period passenger traffic in the metropolis, producing a commensurately dense traffic in regular "protection" fees to LTFRB staff and various law-enforcement officers. Small wonder that neither would-be manufacturers of new vehicles nor government officials tasked with drafting and implementing new transport route plans have overcome the skepticism and resistance which greeted the PUVMP in 2017.

Thus as of early 2020, this ambitious government reform program appeared to have died a natural death, as seen in the quiet dropping of the PUVMP from the DOTr's budgetary planning for the next fiscal year. With the official deadline for meeting the new requirements in mid-2020, a protracted legal limbo awaits, with franchises and routes to be extended - and then re-extended - on a provisional basis by the LTFRB. In the end, the government's seemingly ambitious, eco-friendly, and efficiency-enhancing reform program appears only to have extended and exacerbated the uncertainty and insecurity within which thousands of jeepney drivers are forced to operate every day, as they struggle to find passengers, navigate

\footnotetext{
${ }^{35}$ Cabrera 2018; Tuquero 2019.
} 
traffic, pay daily "boundary" and "protection" in order to make a modest living and provide millions of Filipinos with public transportation in Metro Manila.

\section{Conclusion: Crisis as imperative and opportunity for transformative reform?}

This article has sketched the broad structural contours - and suggested something of the intricate internal workings - of the ecosystem producing and reproducing transportation flows and traffic gridlock in Metro Manila, while demonstrating the resilience and resistance of this ecosystem to transformation through various efforts at reform. An appreciation of the complex linkages between transportation, economic growth, land-use patterns, and real-estate development is a trademark strength of transport studies scholars. This article has extended this kind of systemic analysis to incorporate an understanding of the importance of the economic, institutional, and political contexts within which Metro Manila's transportation system is embedded. The preceding snapshots of various efforts to transform this system through reform have served the dual purpose of illustrating some of the constituent elements - or species - of this ecosystem and illuminating this system's enduring strength and self-reproducing quality as it encounters, incorporates, and adapts to processes and pressures associated with demographic, economic, political, and technological changes. The introduction of new species within this eco-system - P2P bus services, automobile- or motorcycle-based TNVS, and urban transport reform advocacy groups - have induced processes of evolutionary change, but ones characterized by absorption and re-equilibration rather than crisis and transformation.

If the broader environment in which Metro Manila's transportation ecosystem has been embedded is one in which demographic and economic growth have created climate change generating increased pressures that force adaptation but not transformation, what about the sudden crisis created by the global COVID-19 pandemic and the resultant lockdown and drastic 
reduction of economic activity, mobility, and traffic in the National Capital Region? With the imposition of an enhanced community quarantine (ECQ) across Metro Manila and the rest of Luzon in March 2020, public transport slowed to a trickle in the metropolis, as did private automobile and motorcycle traffic.

Against this backdrop, urban transport reform advocacy groups merged to create a \#MoveAsOne Coalition by early May 2020 and drafted a blueprint for the reorganization of Metro Manila's transportation system in the context of the crisis. In this blueprint for reform, the short-term imperative of protecting public health through social distancing was treated as consistent with the longer-term imperative of promoting mobility through systemic reform. Thanks to the newly formed \#MoveAs One Coalition advocates' active presence in the traditional media, on social media, and through their access to Duterte administration officials, they succeeded in presenting this blueprint leading DOTr officials, key legislators in both houses of Congress, other key policymakers, and the public at large.

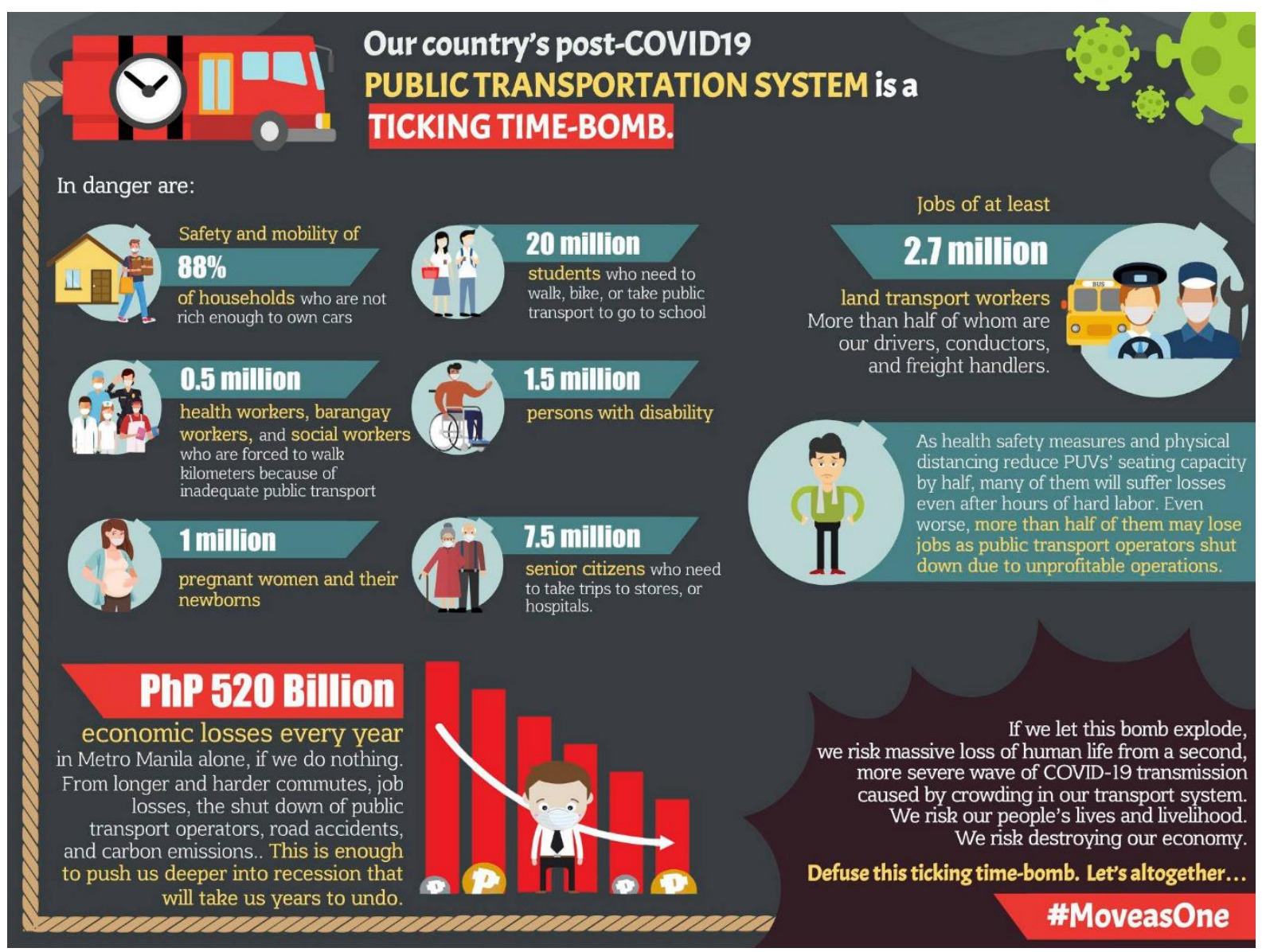


As the Duterte administration initiated a shift from its initial ECQ to a less stringent modified community quarantine (MCQ) in mid-May 2020, the challenges of renewed traffic demanded urgent action. To cope with this sudden resurgence of traffic, the blueprint presented by the \#MoveAsOne Coalition recommended a set of measures to reduce the dangers of a second wave of the COVID-19 virus transmitted via the national capital region's transportation system.

Some of the recommended precautionary measures are self-evidently sensible and straightforward. Rail, bus, and other public transport vehicles should operate at a maximum of fifty percent capacity, with passengers spaced out to maintain social distancing. Masks should be mandatory for both passengers and drivers, temperature checks required prior to boarding, and impermeable barriers separating drivers and passengers installed. Vehicles, transport depots, and offices should be disinfected at least twice a day. The blueprint recommends similar measures for taxis, transportation network vehicle services (TNVS), and motorized tricycles that provide the first and last miles of daily commutes.

But the \#MoveAsOne Coalition's recommendations include a much more systemic reorganization of Metro Manila's urban transportation system, in line with both the short-term exigencies of the pandemic and the longer-term imperatives of reducing traffic congestion in the national capital region once all restrictions on movement are lifted. These recommendations address the difficulties of controlling the supply of public transport and constraining curb-side competition for passengers, the economic pressures on drivers to overload vehicles, and the risks of virus transmission accompanying the payment of fares in cash. In this context, coalition has recommended the following major policy changes: 
- A shift of all road-based public transport in the national capital region to government contracted vehicles, including trunk routes contracted by the DOTr and feeder routes contracted by local governments;

- Free bus and jeepney rides until a cashless fare collection system is established;

- A network of streets closed to vehicular traffic, improved and widened sidewalks, and protected bike lanes.

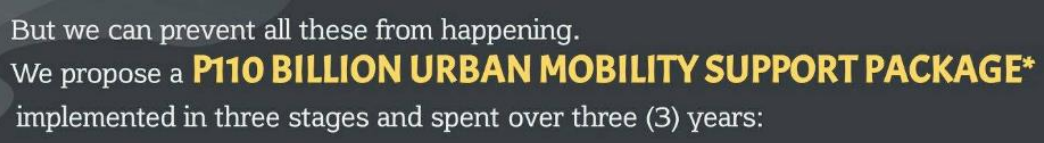

\section{COST}
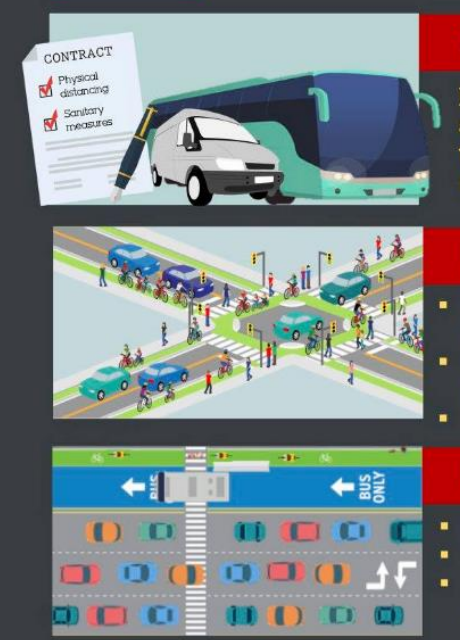

\section{Php 110billion}

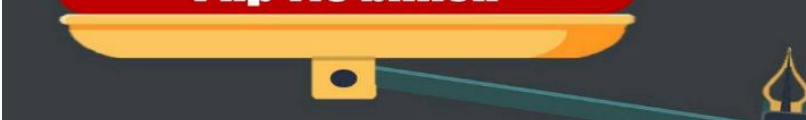

Php 30 billion

Engaging 3,000 buses

and 15,000 other PUVs

through service

contracts for 6 months

Php 10 billion

Walking and cycling

infrastructure

Bicycle sharing/lending

programs

Bike racks

Php 70 billion

Bus stops

bus-only lanes

Depots and

terminals

\section{BENEFIT}

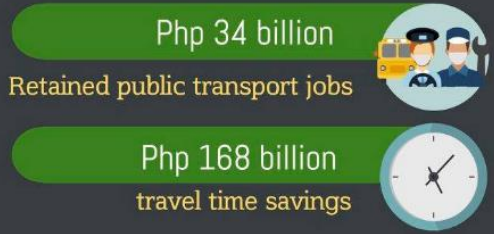

travel time savings

Php 78 billion

Avoided job losses of commuters

Php 12 billion

Fuel and Vehicle Operating Cost Savings

Php 28 billion

Pollution reduction

Php 53 billion

Road accident reduction

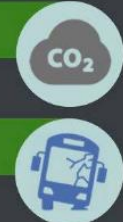

PhP373 Billion

These recommendations are fully in line with urban transport reform advocates' holistic vision of a more efficient, equitable, and eco-friendly transportation system for the national capital region. Unfortunately, a plethora of obstacles stands in the way of the adoption of these recommendations by the Philippine government, at least the more ambitious and costly measures requiring public investment in Metro Manila's transportation system. Commentators often allude to the limited receptivity to such plans shown by DOTr Secretary Arthur Tugade, 
a stance usually attributed to his reported standoffishness and short-temperedness in the face of policy advice proffered from outside his own circle of personal advisors. But, as suggested above, the underlying impediments to a reorganization of Metro Manila's public transportation system are much more structural and systemic, and they remain stubbornly strong even in the face of the ongoing public health crisis.

On the one hand, the institutional arrangements and resources for government oversight of, and investment in, the region's transportation system are woefully inadequate for the purposes of implementing systemic reform. The Department of Transportation (DOTr) itself has a very limited plantilla (permanent staff) and little in the way of institutional memory or capacity, with a pronounced reliance on short-term contractors and consultants. The DOTr, moreover, shares authority over Metro Manila's transportation system with a set of ancillary and attached agencies, many of whose heads enjoy both formal prerogatives and personal/political linkages which undermine effective oversight by the DOTr Secretary. The Land Transportation Franchising and Regulatory Board (LTFRB), for example, is run by a long-time associate of President Duterte from their hometown of Davao City, while the separate Land Transportation Office (LTO) is overseen by a former Director-General of the Philippine National Police (PNP), and the Light Rail Transit Authority (LRTA) is led by a former PNP Intelligence chief who was once convicted for his role in a series of kidnappings in the 1990s. At the same time, the seventeen elected mayors of the constituent cities (and one municipality) of Metro Manila and the Metro Manila Development Authority (MMDA) are involved in traffic enforcement and other forms of transport regulation that overlaps and conflicts with the powers and prerogatives of the DOTr and its agencies.

In addition, the private business interests controlling the commanding heights of Metro Manila's transportation system are pitted against the agenda for holistic reform. A small cluster of diversified conglomerates have vested interests in automobile sales, private toll roads, and 
the slow, selective expansion of the limited rail system. A larger and looser cartel of bus companies seeks to protect its lucrative franchises and preserve the so-called boundary system that leaves financial and physical risks with bus drivers and ticket collectors, while ensuring steady daily rents for their existing fleets of vehicles. These private interests are heavily invested in the status quo, well represented within the agencies of the national government, in Congress, and in city halls across Metro Manila, and consequently ill-disposed towards holistic urban transport reform.

Thus as of late June 2020, prospects for the adoption of the \#MoveAsOne Coalition's blueprint for reorganizing public transport in Metro Manila to meet the challenges of the COVID-19 crisis appear to be restricted by enduring structural and systemic constraints. DOTr has issued a set of guidelines for local governments which have enabled and encouraged the creation of bicycle lanes and the improvement and expansion of pedestrian walkways across key areas of the metropolis, including its central business districts. At the same, time, DOTr has also initiated a limited scheme for "service contracting" buses on an expanding number of routes, with dedicated lanes on major thoroughfares like Epifanio De los Santos Avenue (EDSA). On the other hand, with light rail and bus services still heavily restricted, the easing of the quarantine has left commuters in Metro Manila with even more glaringly inadequate public transportation options than ever, amidst a deepening economic downturn and increasingly frequent downpours in the annual rainy season. The ban on motorcycle taxis, reimposed in mid-March 2020 during the initial quarantine, is now back in place, and DOTr has limited jeepney traffic to the small numbers of modernized vehicles which meet the standards of the PUVMP on routes approved under the Omnibus Franchising Guidelines. The proposed stimulus package for the urban land transport sector has yet to win endorsement, either from DOTr or from Congress, even as pressures have continued to mount for a government bailout of the two airlines sharing control over passenger air traffic across the archipelago (i.e. 
Philippine Air Lines and Cebu Pacific Air), with the major corporate and banking interests involved making their influence felt within the Duterte administration and the legislature. Thus it appears that, through some mix of adaptation and innovation by transport reform advocates, government policymakers, private transport company owners and operators, and commuters, the urban transport ecosystem of Metro Manila - and its dominant species, the privately owned automobile - will survive the ongoing crisis essentially intact.

Acknowledgements: The author would like to thank Toix Cerna and Robie Siy for their assistance and encouragement with the research and analysis, and Emma Colven, Erik Harms, Sylvia Nam, and Bob Shepherd for their astute comments, questions, and suggestions for revisions on successive drafts of this article.

About the Author: John T. Sidel is the Sir Patrick Gillam Professor of International and Comparative Politics at the London School of Economics and Political Science (LSE). He is the author of several books on Southeast Asia, most recently (with Jaime Faustino) Thinking and Working Politically in Development: Coalitions for Change in the Philippines (The Asia Foundation, 2020), and Republicanism, Communism, Islam: Cosmopolitan Origins of Revolution in Southeast Asia (Cornell University Press, in press). 


\section{References}

ALMEC Corporation. 2017. Follow-Up Survey on Roadmap for Transport Infrastructure Development for Greater Capital Region (GCR). Tokyo/Manila: Japan International Cooperation Agency/Republic of the Philippines National Economic Development Authority.

Amojelar, Darwin G. 2016. "Cavite LRT Project Faces Delay," Philippine Daily Inquirer, April 19, 2016.

Avecilla, Victor. 2014. "MMDA's Francis Tolentino and LTFRB's Ariel Inton," Manila Standard, October 14, 2014.

Barry, John and Kaenzig, Robin. National Urban Mobility Program: EDSA-Bus Case Study: Operations and Business Model. Bonn/Eschborn: Deutsche Gesellschaft für Internationale Zusammenarbeit (GIZ).

Biona, Jose Bienvenido, Alvin Mejia, Mark Tacderas, Nathaniel dela Cruz, Kathleen Demetera and Jane Romero. 2017. Alternative Technologies for the Philippine Utility Jeepney: A CostBenefit Study. Pasig City: Blacksmith Institute and Clean Air Asia Center.

Boquet, Yves A. 2019. "Landscapes of Mobility in Metro Manila's Business Districts." MUHON: A Journal of Architecture, Landscape Architecture, and the Designed Environment, 6: $19-30$.

Cabrera, Romina. 2018. "Yearender: Government Fails to Meet PUV Modernization Targets - LTFRB," Philippine Star, December 26, 2018.

Chanco, Boo, 2019a. "Ideas Bloom on Traffic Fix,” Philippine Star, October 4, 2019.

Chanco, Boo, 2019b. “Just Do It!," Philippine Star, September 11, 2019.

Department of Transportation (DOTr). 2019. "General Guidelines for the Pilot Implementation of Motorcycle Taxis. Mabalacat, Pampanga: Department of Transportation of the Philippines.

Department of Transportation (DOTr). 2017. "Department Order Number 2017-011: Omnibus Guidelines on the Planning and Identification of Public Road Transportation Services and Franchise Issuance or Omnibus Franchising Guidelines (OFG). Mandaluyong City: Department of Transportation of the Philippines.

Department of Transportation (DOTr), Department of the Interior and Local Government (DILG), and Land Transportation Franchising and Regulatory Board (LTFRB). 2017. Local Public Transport Route Plan Manual. Mandaluyong City/Quezon City: Department of Transportation (DOTr), Department of the Interior and Local Government (DILG), and Land Transportation Franchising and Regulatory Board (LTFRB).

De Vera, Ben O. 2018. “JICA: Traffic Congestion Now Costs P3.5 Billion a Day," Philippine Daily Inquirer, February 22, 2018.

Domingo, Sonny N., Roehlano M. Briones and Debbie Gundaya. 2015. Diagnostic Report on the Bus Transport Sector. Quezon City: Philippine Institute for Development Studies. 
Elemia, Camille, 2015a. "Corruption at the LTO, LTFRB: Unfit Drivers, Vehicles on the Road," Rappler, July 11, 2015.

Elemia, Camille, 2015b. "Corruption at the LTO, LTFRB: Fixers and Bribes," Rappler, July $12,2015$.

Flyvberg, Bent. 1998. Rationality and Power: Democracy in Practice. Chicago, IL: University of Chicago Press.

Galingan, Zenaida, Paulo G. Alcazaren, Grace C. Ramos, and Romeo B. Santos. 2009. "Pedestrian-Friendly Streets in a Tropical Business District." MUHON: A Journal of Architecture, Landscape Architecture, and the Built Environment, 3: 9-15.

Gopakumar, Govind. 2020. Installing Automobility: Emerging Politics of Mobility and Streets in Indian Cities. Cambridge, MA: MIT Press.

Gutierrez, Ben Paul B. and Rafael Rodriguez. 2013. "Diversification Strategies of Large Business Groups in the Philippines." Philippine Management Review, 20: 65-82.

Holmes, Ronald D. 2016. "The Dark Side of Electoralism: Opinion Polls and Voting in the 2016 Philippine Presidential Election." Journal of Current Southeast Asian Affairs, 35 (3): 1538.

Institute for Transportation and Development Policy/Asian Development Bank. 2016a. Central Corridor BRT: Conceptual Study. New York/Pasig City: Institute for Transportation and Development Policy/Asian Development Bank.

Institute for Transportation and Development Policy/Asian Development Bank. 2016b. Metro Manila Greenways: Conceptual Study. New York/Pasig City: Institute for Transportation and Development Policy/Asian Development Bank.

Integrated Transport Planning. Metro Manila Road Transit Rationalisation Study: Final Report. Manila: The World Bank/Department of Transportation and Communications, 2014.

Intelligent Transport Society of Korea. 2018. A Feasibility Study on Metro Manila's PTIMC Implementation. Seoul: Intelligent Transport Society of Korea.

Johansson, Stefan. 2016a. Case Study for Ebus Quality Services Along EDSA. Stockholm: Swedfund/Sweco.

Johansson, Stefan. 2016b. Republic of the Philippines Public Transit Institutional Study. Stockholm: Swedfund/Sweco.

Land Transportation Franchising and Regulatory Board (LTFRB). 2018. "Memorandum Circular Number 2018-006: Guidelines for the Public Utility Vehicle Modernization Program's Initial Implementation Pursuant to Department Order No. 2017-11, Otherwise Known As The Omnibus Franchising Guidelines." Quezon City: Land Transportation Franchising and Regulatory Board (LTFRB). 
Madarang, Catalina Ricci S. 2020. "Sudden Change in Policy for Motorcycle Taxis Raised Some Suspicions.” Interaksyon, January 23, 2020.

Mateo-Babiano, Iderlina. 2016. "Pedestrian's Needs Matter: Examining Manila's Walking Environment." Transport Policy 45: 107-115.

Metro Manila Development Authority. 1995. "MMDA Regulation No. 95-001 Regulating the Volume of Private Vehicles in Identified Critical Thoroughfares in Metro Manila Through the Vehicular Volume Reduction Program.” Makati City: Metro Manila Development Authority.

Mettke, Christian, Danielle Guillen, and Cristina Villaraza. Transforming Public Transport in the Philippines: The Jeepney+ NAMA of the Philippine Government. Mandaluyong City/Eschborn: Department of Transportation (DOTr) of the Philippines/Deutsche Gesellschaft für Internationale Zusammenarbeit (GIZ).

Real, John Roy Robert G. Jr. 2010. "The Multi-Franchise System in Public Utility Bus Operations: Effects on Market Efficiency." Master of Business Administration and Juris Doctor Thesis, De La Salle University - Graduate School of Business and Far Eastern University - Institute of Law.

Siy, Robert Anthony. 2015. "Coding is Not the Cure to Metro Manila Traffic," Rappler, September 4, 2015.

Talampas, Rolando. 2017. "Transport and Mobility: The Filipino Via Crucis." In Cars, Automobility and Development in Asia: Wheels of Change, edited by Arve Hansen and Kenneth Bo Nielsen, 120-133. London: Routledge.

Tiglao, Rigoberto D. 2016. Colossal Deception: How Foreigners Control Our Telecoms Sector: A Case Study of Corruption, Cronyism and Regulatory Capture in the Philippines. Manila: Strong Republic Books/Manila Times Publishing Corporation.

Tsebelis, George. 2002. Veto Players: How Political Institutions Work. Princeton, NJ: Princeton University Press.

Tuquero, Loreben. 2019. "PUV Modernization 97\% Behind Target Number of Vehicles, DOTr Admits, Rappler, October 3, 2019.

Valdez, Denise A. 2019. "San Miguel Looking to Build an Elevated Expressway on EDSA," Business World, September 19, 2019.

Valdez, Denise A. "Tugade Cites Hurdles for Planned BRT in Cebu, Metro Manila," Business World, May 27, 2018. 